\title{
The possible role of anaerobic bacteria in the aetiology of non-gonococcal urethritis in men
}

\author{
ANDERS HALLÉN,* ANN-CHRISTINE RYDÉN,† ANNA SCHWAN, \\ AND JOHAN WALLIN* \\ From the *Department of Dermatology and Venereology and the †Department of Clinical Bacteriology, \\ University of Uppsala, Sweden
}

SUMMARY Men with non-gonococcal urethritis (NGU) were divided into two groups and treated with either lymecycline or tinidazole ; anaerobic cultures were performed before and after treatment. Neither treatment affected the anaerobic flora. However, the men treated with lymecycline were relieved of symptoms and signs, while those treated with tinidazole were not. The anaerobic bacteria found are considered normal inhabitants of the urethral tract and without significance in the aetiology of NGU.

\section{Introduction}

Non-gonococcal urethritis (NGU) is considered in many areas of the world to be the most common sexually transmitted disease. The Expert Committee on Venereal Diseases for the World Health Organisation of the United Nations recommended in 1948 that 'in view of reports from many countries on the increasing importance of genito-infections of unclassified or ill-defined origin, the possibility of new entities of venereal infections being recognised in the future should be stressed. Collection of data on these conditions is desirable' (cited by Harkness, 1950).

During the last few years several reports have been presented indicating that Chlamydia might be responsible for about $40 \%$ of the cases of NGU (Holmes et al., 1975). There is also reason to believe that a small percentage of NGU is caused by other micro-organisms, such as Ureaplasma urealyticum and herpes virus type 2 (Catterall, 1973). In about $50 \%$ of cases the aetiology of NGU is still unexplained. In two recent studies neither group B streptococci (Wallin and Forsgren, 1975) nor the oral flora (Forsum et al., 1977) was of any significant importance for the presence of clinical symptoms or signs of genital infections.

During the past few years there has been growing interest in anaerobic infections, including infections

Address for reprints: A. Hallén, Department of Dermatology and Venereology, University Hospital, 75014 Uppsala, Sweden

Received for publication 16 May 1977 of the urinary tract. Hafiz et al. (1975) isolated Clostridium difficile from the urethra of 42 men with NGU but not from a group of men attending a general urological clinic. They thought $C$. difficile could be the cause of NGU. The main purpose of the present study was to evaluate the importance of anaerobic bacteria in the development of genital disease in men. This was done by culturing anaerobes from the urethra of men with NGU and by studying the effects of treatment on clinical symptoms and on growth of anaerobic bacteria. Lymecycline (Tetralysal®), a tetracycline product known to be effective in treating men with NGU (Willcox, 1972), was given to one group, and tinidazole (Fasigyn (B)), a nitroimidazole, with high activity in vitro against anaerobic pathogens (Dornbusch and Nord, 1974), was given to the other.

\section{Material and methods}

Men attending the venereal diseases clinic complaining of dysuria and/or urethral discharge and with an increase of urethral leucocytes (next page) were studied. Patients who had had antibiotics during the previous two weeks, those who had intraurethral warts, and those who could not return for a second visit were excluded. The number of men studied was 43. They were aged between 20 and 38 years (mean 26 years).

\section{CLINICAL PROCEDURE}

The selected patients were asked not to urinate for at least three hours before examination. With a 
sterile plastic loop a specimen of the urethral discharge was collected and a direct smear stained with methylene blue. The smear was examined microscopically for polymorphonuclear leucocytes (PMN) and Gram-negative intracellular diplococci (GNID). NGU was diagnosed if 10 or more PMN were found per high-power field (HPF) in 10 fields, using $\times 100$ objective and a 12.5 ocular, in the absence of GNID. The diagnosis was confirmed by negative gonococcal culture from a specimen taken with a charcoal-coated cotton swab inserted $1 \mathrm{~cm}$ into the urethra. Specimens for the culture of anaerobic bacteria were taken with a sterile cotton swab inserted $2 \mathrm{~cm}$ into the urethra and sent to the laboratory in a modified Stuart's medium (Gästrin et al., 1968).

The patients were asked not to have sexual intercourse during the time of the study and to return for a follow-up visit 14 days after treatment had started. Symptoms were then recorded, smears prepared for microscopical examination, and specimens taken for anaerobic culture.

\section{TREATMENT}

The men were divided into two groups: those born in an even year ( 23 men) were treated with lymecycline (Tetralysal ${ }^{\circledR}$ ) $\mathbf{0 . 3} \mathrm{g}$ twice daily for one week. Those born in an odd year (19 men) were treated with tinidazole (Fasigyn $\left.{ }^{\circledR}\right) \quad 0 \cdot 15 \mathrm{~g}$ twice daily for one week.

\section{BACTERIOLOGICAL METHODS}

The specimens were cultured within two hours of collection. The media used for the aerobes included blood agar with and without gentian violet, haematin agar, and phenol-red-mannitol agar. The plates were incubated at $37^{\circ} \mathrm{C}$, the haematin agar and the gentian violet agar plates in an atmosphere containing $5 \%$ carbon dioxide.

For the isolation of gonococci, GC agar base (BBL, Maryland, USA) was used with the addition of $2 \%$ haemoglobin (BBL) and $1 \%$ IsoVitaleX (BBL). Selective agar was also used, prepared as above with the addition of $1 \%$ vancomycin-colistinnystatin (BBL). Each sample was cultivated on both media. Oxidase positive colonies were examined using the immunofluorescent technique described by Forsum (1972).

For isolation of anaerobic bacteria, brain heart infusion agar base (Difco, Detroit, Michigan, USA) with the addition of $0.5 \%$ yeast extract (Difco), $5 \%$ sheep blood, menadione $(0.5 \mathrm{mg} / \mathrm{l}$, Sigma Chemical Co., St Louis, Mo., USA) and haemin ( $5 \mathrm{mg} / \mathrm{l}$, Sigma Chemical Co.) was used. The plates were used within two hours of preparation and incubated anaerobically at $37^{\circ} \mathrm{C}$ using the Gas Pak ${ }^{\circledR}$ system (BBL, Maryland, USA).
Aerobic plates were examined after 24 and 48 hours. The anaerobic jars were opened after 48 hours. If there was no growth, the plates were incubated for another two days. Aerobic bacteria were identified according to standard biochemical procedures. The anaerobic bacteria were characterised by Gram stains and gas chromatographic analyses performed as described by Holdeman and Moore (1972). For sensitivity testing the technique of Ericsson and Sherris (1971) was used. The agar was the same as for the original anaerobic cultivation. The bacteria were suspended carefully, without blowing, in sterile sodium chloride $(0.85 \%)$ and flooded on each plate. Excess suspension was removed and the plates dried at $37^{\circ} \mathrm{C}$. Impregnated antibiotic discs were then applied to the plates which were incubated for 48 hours at $37^{\circ} \mathrm{C}$ in Gas Pak ${ }^{\circledR}$ anaerobic jars.

\section{Results}

Tables 1 and 2 present the bacteriological findings from the urethral discharge of men with NGU

Table 1 Aerobic bacteria isolated from urethral discharge from 43 men with NGU before and after treatment with lymecycline or tinidazole

\begin{tabular}{|c|c|c|c|c|}
\hline \multirow[b]{3}{*}{ Aerobic bacteria } & \multirow{2}{*}{\multicolumn{2}{|c|}{$\frac{\text { Lymecycline }}{\text { No. of isolates }}$}} & \multirow{2}{*}{\multicolumn{2}{|c|}{$\frac{\text { Tinidazole }}{\text { No. of isolates }}$}} \\
\hline & & & & \\
\hline & $\begin{array}{l}\text { Before } \\
\text { treatment }\end{array}$ & $\begin{array}{l}\text { After } \\
\text { treatment }\end{array}$ & $\begin{array}{l}\text { Before } \\
\text { treatment }\end{array}$ & $\begin{array}{l}\text { After } \\
\text { treatment }\end{array}$ \\
\hline Staphylococcus aureus & 0 & $\mathbf{0}$ & $\mathbf{0}$ & 3 \\
\hline Staphylococcus albus & 7 & 16 & 14 & 9 \\
\hline Alpha-streptococci & 7 & 5 & 9 & 3 \\
\hline \multicolumn{5}{|l|}{ Beta-streptococci } \\
\hline Group B & 1 & 1 & 2 & 3 \\
\hline \multicolumn{5}{|l|}{ Beta-streptococci } \\
\hline other groups & 0 & 2 & 1 & 0 \\
\hline Diphteroids & 3 & 1 & 3 & 5 \\
\hline
\end{tabular}

Table 2 Anaerobic bacteria isolated from urethral discharge from 43 men with NGU before and after treatment with lymecycline or tinidazole

\begin{tabular}{|c|c|c|c|c|}
\hline \multirow[b]{3}{*}{ Anaerobic bacteria } & \multirow{2}{*}{\multicolumn{2}{|c|}{$\frac{\text { Lymecycline }}{\text { No. of isolates }}$}} & \multirow{2}{*}{\multicolumn{2}{|c|}{$\frac{\text { Tinidazole }}{\text { No. of isolates }}$}} \\
\hline & & & & \\
\hline & $\begin{array}{l}\text { Before } \\
\text { treatment }\end{array}$ & $\begin{array}{l}\text { After } \\
\text { treatment }\end{array}$ & $\begin{array}{l}\text { Before } \\
\text { treatment }\end{array}$ & $\begin{array}{l}\text { After } \\
\text { treatment }\end{array}$ \\
\hline Peptococcus sp. & 20 & 16 & 15 & 18 \\
\hline Peptostreptococcus sp. & 4 & 2 & 1 & 3 \\
\hline Lactobacillus sp. & 3 & 2 & 0 & 2 \\
\hline Propionibacterum sp. & 3 & $\overline{1}$ & 1 & 1 \\
\hline Eubacterium sp. & 1 & 0 & 1 & 1 \\
\hline Clostridium sp. & 2 & 1 & 1 & 0 \\
\hline Gram-positive rods & 1 & 3 & 1 & 0 \\
\hline Veillonella sp. & 0 & 0 & 1 & 0 \\
\hline Bacteroides sp. & 2 & $\mathbf{0}$ & 1 & 2 \\
\hline Gram-negative rods & 2 & 0 & 0 & 0 \\
\hline
\end{tabular}


before and after treatment with either lymecycline or tinidazole. There was no reduction of the aerobic or anaerobic flora after either treatment. After treatment with lymecycline $87 \%$ of the men had no symptoms compared with $37 \%$ who were given tinidazole (Table 3).

Table 3 Effect of treatment on men with NGU

\begin{tabular}{llllll}
\hline & \multicolumn{2}{l}{ Lymecycline } & & \multicolumn{2}{l}{ Tinidazole } \\
\cline { 2 - 3 } \cline { 6 - 6 } \cline { 5 - 6 } & \multicolumn{2}{l}{ No. of patients $(\%)$} & & No. of patients $(\%)$ \\
\hline No symptoms & 20 & $(87)$ & 7 & $(37)$ \\
Better & 3 & $(13)$ & 7 & $(37)$ \\
Unchanged & 0 & $(0)$ & 5 & $(26)$ \\
\hline
\end{tabular}

Table 4 Findings of $P M N$ by direct microscopical examination after treatment of men with $N G U$

\begin{tabular}{llllll}
\hline & \multicolumn{2}{l}{ Lymecycline } & \multicolumn{3}{l}{ Tinidazole } \\
\cline { 2 - 3 } No. of PMN/HPF & \multicolumn{2}{l}{ No. of patients $(\%)$} & \multicolumn{2}{l}{ No. of patients $(\%)$} \\
\hline 0 & 11 & $(48)$ & 1 & $(5)$ \\
$1-10$ & 8 & $(35)$ & 2 & $(11)$ \\
$\geqslant 10$ & 4 & $(17)$ & 16 & $(84)$ \\
\hline
\end{tabular}

The number of leucocytes in the urethral smears after treatment is shown in Table 4. An increase in the number of cells was found in $17 \%$ of the patients receiving lymecycline and in $84 \%$ of those given tinidazole.

The bacteriological cultures from the urethra and cervix of the female partners of 12 of the men with NGU yielded the same aerobic and anaerobic bacteria as from the male urethra, irrespective of symptoms or signs in the women. Different bacteria were found in the men and their partners.

Antibiotic sensitivity testing of the isolated strains showed that more than half the Gram-positive cocci isolated were sensitive to the tetracycline group of antibiotics. This was also true for the Clostridia and Lactobacilli isolated. Unfortunately, tinidazole was not available for sensitivity testing at the time of the study. Testing of anaerobes later isolated from clinical specimens however have shown that about $90 \%$ of the Bacteroides and the Clostridia are sensitive to metronidazole, while about $30 \%$ of the Gram-positive cocci and $60 \%$ of the Lactobacilli are resistant.

\section{Discussion}

The aerobic and anaerobic bacteria isolated from the urethra of men with NGU correspond well with what are considered to be normal findings in other reports (Finegold et al., 1965; Gorbach and
Bartlett, 1974; Weinberg, 1974; Smith, 1975). Although anaerobes could be isolated from almost every case of NGU no single positive culture of $C$. difficile was found. This is in sharp contrast with the results of Hafiz et al. (1975) who found $C$. difficile in $100 \%$ of men with NGU but in none of the men attending a urological clinic. The difference cannot be explained by lack of appropriate sampling and cultivating techniques, as at the same time we found strains of $C$. difficile in samples from other patients examined. $C$. difficile is easy to identify as it has a characteristic gas chromatographic pattern. Unfortunately, the method used by Hafiz et al. (1975) to identify the organism is not known to us and we lack clinical information about their urological patients. Hafiz et al. (1975) found $C$. difficile in $71 \%$ of women attending a special clinic, compared with only $18 \%$ in women attending a family planning clinic. In the absence of clinical details concerning these women we cannot evaluate this difference. We did not find $C$. difficile in any of our female patients.

Treatment of NGU with lymecycline improved the signs of NGU in $83 \%$ and the corresponding figure for tinidazole was $16 \%$. Neither treatment altered the anaerobic flora in the urethra, although most of the anaerobic strains were found to be sensitive to both antibiotics as reported by Martin et al. (1972). One probable explanation could be that anaerobes multiplied during the period between the end of treatment and the follow-up visit. The predominance of anaerobic bacteria in the bowel and in the perineal area (Attebery et al., 1974; Weinberg, 1974; Smith, 1975) might explain such a fast colonisation.

Nothing was found to suggest that anaerobic bacteria were important for the development of NGU in men.

Bacteroides fragilis, the anaerobic bacterium which is predominant in the bowel, has also been isolated from the cervix of healthy women (Gorbach et al., 1973). This organism is well known not only in cases of pelvic inflammatory disease, like salpingitis, but also in lower genital tract infections in women, like Bartholin's abscess (Swenson et al., 1973). We did not isolate $B$. fragilis from any case of NGU. The lower genital tract of men certainly has anaerobic recesses, like the paraurethral ducts, the seminal vesicles, and the prostate where $B$. fragilis might readily grow, but the anatomical differences make a heavy spread from the anorectal reservoir less likely in men. However, male homosexuals with rectal coitus must be considered a high-risk group for this kind of infection.

It is not known if the presence of anaerobic bacteria in the genital urethral flora is important, 
and further study is required to determine whether a disturbance in this flora is an important factor in cases of NGU still lacking aetiological explanation. In this study we did not get any longstanding changes in the anaerobic flora with one week's treatment with lymecycline or tinidazole. Therefore from this point of view these drugs seem safe to use in genitourinary infections.

The capable technical assistance of Miss Olga Svensson is gratefully acknowledged.

\section{References}

Attebery, H. R., Sutter, V. L., and Finegold, S. H. (1974). Normal human intestinal flora. In Anaerobic Bacteria: Role in Disease, pp. 81-97. Edited by A. Balows, R. M. Dehaan, V. R. Dowell, and L. B. Guze. Thomas: Springfield.

Catterall, R. D. (1973). Non-gonococcal urethritis. In Proceedings of the Second International Venereal Disease Symposium, St Louis, April 1972, pp. 78-82. Pfizer: New York.

Dornbusch, K., and Nord, C-E. (1974). In vitro effect of metronidazole and tinidazole on anaerobic bacteria. Medical Microbiology and Immunology, 160, 265-267.

Ericsson, H. M., and Sherris, J. (1971). Antibiotic sensitivity testing. Report of an international collaborative study. Acta pathologica et microbiologica Scandinavica $(B)$, Supplement 217.

Finegold, S. M., Miller, L. G., Merrill, S. L., and Posnick, D. J. (1965). Significance of anaerobic and capnophilic bacteria isolated from the urinary tract. In Progress in Pyelonephritis, pp. 159-178. Edited by E. H. Kass. Davis: Philadelphia.

Forsum, U. (1972). Characterisation of FITC-labelled F (ab') 2 fragments of IgG and a rapid technique for the separation of optimally labelled fragments. Journal of Immunological Methods, 2, 183-195.
Forsum, U., Hjelm, E., Holmberg, K., Nord, C-E., and Wallin, J. (1977). Genital occurrence of oral microbiota. (In press).

Gästrin, B., Kallings, L-O., and Marcetic, A. (1968). The survival time for different bacteria in various transport media. Acta pathologica et microbiologica Scandinavica, 74, 371-380.

Gorbach, S. L., and Bartlett, J. G. (1974). Anaerobic infections. New England Journal of Medicine, 290, 1237-1245.

Gorbach, S. L., Menda, K. B., Thadepalli, H., and Keith, L. (1973). Anaerobic microflora of the cervix in healthy women. American Journal of Obstetrics and Gynecology, 117, 1053-1055.

Hafiz, S., McEntegart, M. G., Morton, R. S., and Waitkins, S. A. (1975). Clostridium difficile in the urogenital tract of males and females. Lancet, 1, 420-421.

Harkness, A. H. (1950). Non-gonococcal Urethritis, p. 7. Livingstone: Edinburgh.

Holdeman, L. V., and Moore, W. E. C. (1972). Anaerobe Laboratory Manual. Virginia Polytechnic Institute and State University: Blackburg.

Holmes, K. K., Handsfield, H. H., Wang, S. P., Wentworth, B. B., Truck, M., Andersson, J. B., and Alexander, E. R. (1975). Etiology of non-gonococcal urethritis. New England Journal of Medicine, 292, 1199-1205.

Martin, W. J., Gardner, M., and Washington, J. A. II (1972). In vitro antimicrobial susceptibility of anaerobic bacteria isolated from clinical specimens. Antimicrobial Agents and Chemotherapy, 1, 148-158.

Smith, L. D. (1975). The Pathogenic Anaerobic Bacteria, second edition, pp. 341-363. Thomas: Springfield.

Swenson, R. M., Michaelson, T. C., Daly, M. J., and Spaudling, E. H. (1973). Anaerobic bacterial infections of the female genital tract. Obstetrics and Gynecology, 42, 538-541.

Wallin, J., and Forsgren, A. (1975). Group B streptococci in venereal disease clinic patients. British Journal of Venereal Diseases, 51, 401-404.

Weinberg, A. N. (1974). Infections due to anaerobic cocci. In Anaerobic Bacteria: Role in Disease, pp. 257-265. Edited by A. Balows, R. M. Dehaan, V. R. Dowell, and L. B. Guze. Thomas: Springfield.

Willcox, R. R. (1972). Triple tetracycline in the treatment of nongonococcal urethritis in males. British Journal of Venereal Diseases, 48, 137-140. 